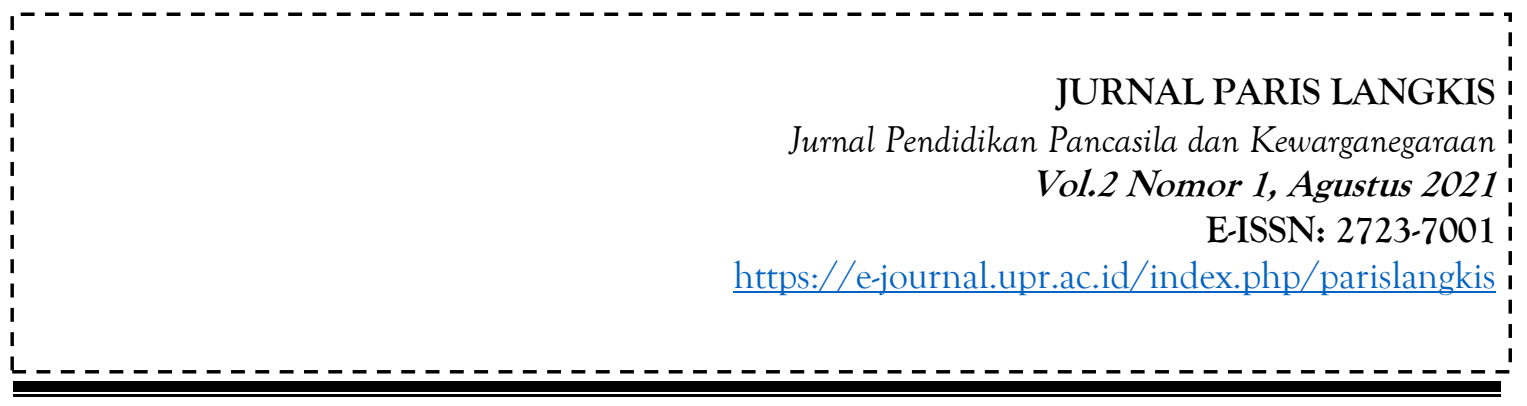

\title{
PENDIDIKAN MORAL DAN RELEVANSINYA DENGAN PENDIDIKAN ISLAM
}

\author{
Mustika Abidin \\ Dosen Universitas Islam Negeri (UIN) Alauddin Makassar \\ Email: mustikaabidin26@gmail.com
}

\begin{abstract}
Abstrak
Pendidikan moral di era modern saat sekarang ini sudah menjadi fenomena kemasyarakatan yang universal. Hampir semua masyarakat modern cenderung menempatkan pendidikan moral sebagai bagian yang urgen dan integral dalam sistem kependidikannya. Selain itu, perlu dipahami bahwa ukuran peradaban suatu bangsa dapat diukur dari sejauhmana tingkat moralitas atau akhlak penduduknya. Moralitas setiap individu merupakan salah satu aspek yang sangat esensial dalam kehidupan. Sehingga, pendidikan moral yang sesuai ajaran Islam menjadi tugas utama pendidikan Islam. Oleh karena itu, konsep pendidikan Islam terhadap moralitas setiap individu harus memperhatikan bimbingan jasmani, rohani, akal, dan sosial berdasarkan hukum-hukum agama Islam agar terbentuknya moralitas yang baik menurut ukuran Islam yaitu al-Qur'an dan hadis sehingga memberikan manfaat bagi semua manusia.
\end{abstract}

Kata Kunci: Pendidikan, Moral, Pendidikan Moral, dan Pendidikan Islam

\section{A. PENDAHULUAN}

Manusia lahir di dunia dalam keadaan fitrah bagaikan kertas putih. Agar dapat memberikan warna dibutuhkan campur tangan dari lingkungan seperti keluarga, masyarakat, dan alam. Salah satu kebutuhan manusia yang paling mendasar adalah pendidikan karena pendidikan merupakan pilar yang sangat penting bagi setiap manusia dan menempati posisi pertama dan strategis dalam menumbuhkan berbagai potensi yang dimiliki oleh setiap manusia yang bisa didapatkan dari pendidikan formal, non formal maupun informal (Machmud, 2014). Pendidikan juga merupakan salah satu kebutuhan manusia selain kebutuhan akan sandang, pangan dan papan. Pendidikan adalah upaya yang ditempuh oleh manusia agar dapat mengubah perilaku sehingga menjadi pribadi yang baik dan mampu mengembangkan pengetahuan yang dimiliki. Pendidikan yang dijalani oleh individu terdapat proses belajar didalamnya dan hasilnya akan membawa perubahan positif dalam kehidupan manusia baik secara individu maupun masyarakat sekitar individu tersebut (Khaironi, 2017). Oleh karena itu,

\section{Paris Langkis}

Vol.2 Nomor 1, Agustus 2021 
keberadaan orang-orang yang berpendidikan di lingkungan masyarakat selalu diperhitungkan. Salah satu pendidikan yang dibutuhkan setiap individu dalam kehidupan adalah pendidikan moral.

Di era modern saat sekarang ini, perilaku moral dan kepribadian masyarakat sungguh memprihatinkan karena adanya berbagai kasus asusila dan amoral yang dilakukan oleh orang dewasa, remaja bahkan anak-anak seperti pembunuhan, penganiayaan, pemerkosaan, pencurian, dan sebagainya. Mencermati kondisi yang ada, maka pendidikan moral merupakan kunci utama dalam membentuk kehidupan manusia ke arah peradaban dan kepribadian yang lebih baik. Menurut Nawawi dalam (Khaironi, 2017) pendidikan moral sangat penting bagi generasi penerus bangsa agar martabat bangsa terangkat, kualitas hidup dapat meningkat, kehidupan menjadi lebih baik, aman, nyaman, dan sejahtera. Pendidikan moral sangat urgen bagi tegaknya suatu bangsa karena tanpa pendidikan moral kemungkinan besar suatu bangsa dapat hancur.

Moral menjadi dasar dalam kehidupan bermasyarakat, berbangsa, dan bernegara. Banyak terjadi permasalahan global di dunia yang berawal dari budaya nilainilai moral yang belum sepenuhnya diajarkan dan dipahami oleh seluruh bangsa-bangsa di dunia karena pada dasarnya moral merupakan cerminan dari implikasi perilaku dan sikap warga negara dalam menjalankan tugas dan tanggung jawabnya sebagai warga negara yang baik. Terdapat beberapa faktor yang merusak moral generasi muda diantaranya perkembangan dan kemajuan teknologi, rendahnya iman, pengaruh pergaulan lingkungan sekitar, dan lain-lain sebagainya. Maka dari itu, hendaknya pendidikan moral menjadi landasan dasar utama bagi negara-negara berkembang agar dapat menghasilkan kualitas sumber daya manusia yang profesional sebagai upaya membangun peradaban manusia yang lebih baik (Sutrisno, 2020).

Pendidikan moral yang bertujuan menjadikan individu menjadi lebih baik juga sejalan dengan pendidikan Islam itu sendiri. Sebagai bagian yang fundamental dalam pembentukan kepribadian manusia, pendidikan Islam merupakan salah satu faktor penunjang dalam pendidikan moral sebagaimana sabda nabi Muhammad SAW: Orang mukmin yang paling sempurna imannya adalah yang paling baik akhlaknya (HR. Abu Dawud dan Tirmidzi). Berdasarkan beberapa uraian yang telah dibahas sebelumnya, maka dari itu penulis perlu mengkaji lebih lanjut mengenai pendidikan moral dan relevansinya dengan pendidikan Islam.

\section{B. METODE PENELITIAN}

Metode penelitian ini menggunakan metode deskriptif analisis yaitu metode penelitian dengan cara mengumpulkan data-data sesuai dengan yang sebenarnya kemudian data-data tersebut disusun, diolah dan dianalisis untuk dapat memberikan gambaran mengenai masalah yang ada (Sugiyono, 2017). Metode ini digunakan yakni dengan melihat beberapa referensi yang berkaitan dengan pembahasan yang dibahas kemudian dikaitkan dengan kajian tentang pendidikan moral dan relevansinya dengan pendidikan Islam.

\section{PEMBAHASAN}

\section{Pendidikan Moral}

Paris Langkis

Vol.2 Nomor 1, Agustus 2021 
Menurut Undang-Undang Sistem Pendidikan Nasional tahun 2003 pasal 1 ayat (1): "Pendidikan adalah usaha sadar dan terencana untuk mewujudkan suasana belajar dan proses pembelajaran agar peserta didik secara aktif mengembangkan potensi dirinya untuk memiliki kekuatan spiritual keagamaan, pengendalian diri, kepribadian, kecerdasan, akhlak mulia, serta keterampilan yang diperlukan dirinya, masyarakat, bangsa dan negara. Menurut Ahmad Tafsir pendidikan merupakan usaha meningkatkan diri dalam segala aspek, yang melibatkan guru maupun tidak, baik formal maupun informal sedangkan menurut Azyumradi Azra pendidikan merupakan suatu proses penyiapan generasi muda untuk menjalankan kehidupan dan memenuhi tujuan hidupnya secara efektif dan efisien. Adapun menurut Zakiyah Darajat pendidikan diartikan sebagai pembinaan, pembentukan, pengarahan, pencerdasan, pelatihan yang ditujukan kepada anak didik secara formal maupun non formal yang bertujuan membentuk anak didik tersebut menjadi cerdas, berkepribadian, memiliki keterampilan atau keahlian sebagai bekal dalam kehidupannya di masyarakat (Rubini, 2019).

Moral menurut (Kamus Besar Bahasa Indonesia, 2017) adalah: (1) Ajaran tentang baik buruk yang diterima umum mengenai perbuatan, sikap, kewajiban, dan sebagainya. (2) kondisi mental yang membuat orang berani, bersemangat, bergairah, berdisiplin, dan sebagainya; isi hati atau keadaan perasaan sebagaimana terungkap dalam perbuatan. (3) ajaran kesusilaan yang dapat ditarik dari suatu cerita. Menurut (Sauri, 2010) moral memiliki makna sebagai berikut: (1) moral merupakan ajaran kesusilaan yaitu segala sesuatu yang berkaitan dengan tuntunan untuk melakukan perbuatan baik dan meninggalkan perbuatan buruk yang bertentangan dengan ketentuan yang berlaku di masyarakat. (2) moral merupakan aturan yaitu ketentuan yang digunakan oleh masyarakat untuk dapat menilai perbuatan seseorang apakah termasuk kategori perbuatan baik atau perbuatan buruk. (3) moral merupakan gejala kejiwaan yang timbul dalam bentuk perbuatan seperti jujur, sabar, berani, dan lainlain sebagainya.

Moral merupakan nilai yang berkaitan tentang baik-buruk kelakuan manusia. Olehnya itu, moral berkaitan dengan nilai terutama nilai afektif (sikap). Moralitas merupakan aspek kepribadian seseorang dalam kaitannya dengan kehidupan sosial secara harmonis, adil dan seimbang. Perilaku moral sangat diperlukan demi terwujudnya kehidupan yang damai, teratur, tertib, dan harmonis (Rubini, 2019). Moral menurut Suseno dalam (Ananda, 2017) merupakan ukuran baik-buruknya seseorang baik sebagai pribadi, warga masyarakat, dan warga negara sedangkan pengertian pendidikan moral adalah pendidikan untuk menjadikan manusia bermoral dan manusiawi. Menurut Ouska dan Whellan dalam (Kurnia, 2015) moral merupakan prinsip baik-buruk yang ada dan melekat dalam diri seseorang dan berada dalam suatu sistem yang berwujud sebagai sebuah aturan.

Pendidikan moral adalah penanaman, pengembangan dan pembentukan akhlak yang mulia dalam diri seseorang. Pendidikan moral merupakan keutamaan tingkah laku yang wajib dilakukan oleh seseorang, diusahakan dan dibiasakan sejak kecil hingga dewasa. Moral seseorang dapat dipupuk dan dikembangkan menuju tingkat perkembangan yang sempurna dalam suatu proses pendidikan (Surur, 2010).

Paris Langkis

Vol.2 Nomor 1, Agustus 2021 
Pendidikan moral menurut (Zuriah, 2011) merupakan suatu program pendidikan baik di sekolah maupun di luar sekolah yang mengorganisasikan dan menyederhanakan sumber-sumber moral dan disajikan dengan pertimbangan psikologis untuk tujuan pendidikan. Pendidikan moral mengarah agar individu dapat menyesuaikan diri dengan tujuan hidup bermasyarakat. Adapun pendidikan moral menurut Zakiyah Daradjat dalam (Fitri, 2016) merupakan pengembangan nilai-nilai atau tata cara untuk mewujudkan titik optimal moral sehingga dapat bersifat dengan baik dan membedakan perbuatan baik dan buruk sehingga dapat hidup bermasyarakat dengan baik. Moral sangat penting karena merupakan kelakuan yang sesuai dengan ukuran-ukuran masyarakat yang timbul dari hati sendiri bukan karena paksaan dari luar, moral merupakan rasa tanggung jawab atas tindakan, dan moral itu mendahulukan kepentingan umum daripada kepentingan pribadi.

Tujuan pendidikan moral menurut (Zuriah, 2011) antara lain:

1) Mampu memahami nilai-nilai budi pekerti di lingkungan keluarga, lokal, nasional dan internasional melalui adat istiadat, hukum, undang-undang dan tatanan antar bangsa.

2) Mampu mengembangkan watak atau tabiat secara konsisten dalam mengambil keputusan yang bijak atau berbudi pekerti ditengah-tengah rumitnya kehidupan bermasyarakat saat ini.

3) Mampu menghadapi masalah nyata dalam masyarakat secara rasional bagi pengambilan keputusan yang terbaik setelah mempertimbangkan dengan norma budi pekerti.

4) Mampu menggunakan budi pekerti yang baik bagi pola perilaku yang berguna dan bertanggung jawab.

Tujuan pendidikan moral menurut Elihami, dkk dalam (Syaparuddin, 2020) yaitu membimbing generasi muda untuk memahami dan menghayati Pancasila secara keseluruhan. Tujuan pendidikan moral yang lain yaitu meningkatkan ketakwaan kepada Tuhan Yang Maha Esa, meningkatkan kecerdasan dan keterampilan dan mempertinggi budi pekerti, memperkuat kepribadian dan mempertebal semangat kebangsaan. Menurut Daroeso dalam (Syaparuddin, 2020) pendidikan moral mempunyai tujuan dan sasaran yaitu: (1) perkembangan individu seutuhnya, (2) membina warga negara yang bertanggung jawab, (3) mengembangkan sikap saling menghormati martabat individu dan kesucian hak asasi manusia, (4) menanamkan patriotisme dan integrasi nasional, (5) mengembangkan cara hidup dan berpikir yang demokratis, (6) mengembangkan sikap toleransi, (7) mengembangkan persaudaraan, (8) mendorong tumbuhnya iman, serta (9) menanamkan prinsip moral.

Menurut (Yusuf, 2014) perkembangan moral individu dapat berlangsung melalui beberapa cara, diantaranya:

1) Pendidikan langsung, yaitu melalui penanaman pengertian tentang tingkah laku yang benar dan salah, baik atau buruk. Selain itu, yang paling penting dalam pendidikan moral adalah keteladanan dari orang tua, guru, atau orang dewasa lainnya dalam melakukan nilai-nilai moral. 
2) Identifikasi, yaitu dengan cara mengidentifikasi serta meniru penampilan atau tingkah laku moral seseorang yang menjadi idolanya.

3) Trial and Error (proses coba-coba), yaitu dengan caramengembangkan tingkah laku moral secara coba-coba dengan ketentuan bahwa tingkah laku yang baik dan mendatangkan pujian akan terus dikembangkan sementara tingkah laku yang buruk dan mendatangkan hukuman/celaan akan dihentikan.

Dalam pendidikan formal, menurut (Surur, 2010) terdapat faktor-faktor yang memegang peranan penting, antara lain: (1) Pembiasaan, maksudnya yaitu diperlukan adanya hadiah terhadap perilaku moral individu jika melakukan tindakan moral yang baik dan diberi hukuman jika melakukan tindakan moral yang buruk. Dari adanya pembiasaan ini, internalisasi nilai moral yang diajarkan akan dapat diwujudkan dalam kehidupan sehari-hari karena individu dapat menyadari perilaku moral yang harus dilakukan dan perilaku moral yang harus dihindari/tidak dilakukan. Selain itu, dengan adanya pembiasaan terhadap perilaku moral maka akan membentuk watak atau tabiat bagi individu. (2) Pengembangan berfikir kritis terhadap alasan dan tujuan perilaku moral, yang didalamnya diperlukan adanya diskusi serta penjelasan terhadap pertimbangan moral yaitu alasan melakukan suatu perilaku moral. Dengan adanya pemikiran kritis maka dimungkinkan dapat mengembangkan perilaku moral yang awalnya berpusat untuk diri sendiri menuju pada perhatian kepada orang lain sehingga dapat memperhatikan nilai-nilai universal.

Berdasarkan beberapa uraian di atas, dapat dipahami bahwa moral merupakan pandangan tentang baik dan buruk, benar dan salah, sesuatu hal yang dapat dilakukan dan tidak dapat dilakukan dalam kehidupan. Moral sangat penting karena apabila moral sudah rusak, maka ketentraman dan kehormatan bangsa akan hilang. Olehnya itu, untuk dapat memelihara kelangsungan hidup sebagai bangsa yang terhormat maka diperlukan adanya pendidikan moral baik di lingkungan keluarga, sekolah maupun masyarakat. Pendidikan moral bertujuan agar dapat membentuk individu yang bermoral yang tidak hanya tampak dari tingkah lakunya tetapi juga alasan bermoral tersebut muncul dalam dirinya. Pendidikan moral sangat penting dan diperlukan agar setiap individu menyadari pentingnya nilai-nilai moral karena nilai moral tersebut dapat dijadikan sebagai pedoman dalam bertingkah laku dan bersikap baik sebagai individu maupun dalam masyarakat.

\section{Pendidikan Islam}

Pendidikan Islam menurut Alim dalam (Rohman \& Hairudin, 2018) merupakan sebuah program yang terencana dalam menyiapkan individu agar dapat mengenal, memahami, menghayati, dan mengimani ajaran agama Islam serta diikuti tuntunan untuk menghormati agama yang lain dalam hubungan antar umat beragama sehingga terwujud persatuan dan kesatuan bangsa. Menurut Sajjad Husain dan Al-Asyraf dalam (Haryanti, 2014) pendidikan Islam merupakan suatu pendidikan yang melatih individu sehingga di dalam sikap hidup, tindakan, keputusan dan pendekatan terhadap segala jenis pengetahuan dipengaruhi dengan nilai spiritual dan semangat sadar akan nilai etis Islam. Individu dilatih mentalnya menjadi disiplin sehingga ingin mendapatkan pengetahuan bukan semata-mata untuk memuaskan rasa ingin

Paris Langkis

Vol.2 Nomor 1, Agustus 2021 
tahu intelektual atau material saja melainkan untuk berkembang menjadi makhluk rasional yang berbudi luhur dan melahirkan kesejahteraan spiritual, moral untuk keluarga, bangsa dan seluruh umat manusia.

Tujuan pendidikan Islam menurut (Syafe'i, 2015) harus berorientasi kepada hakekat pendidikan Islam itu sendiri yang meliputi: (1) Tujuan dan tugas hidup manusia, maksudnya bahwa manusia hidup bukan karena kebetulan dan sia-sia sehingga diharapkan manusia dapat melaksanakan tugas dan tanggung jawabnya kepada Allah SWT dengan sebaik-baiknya. (2) Tujuan pendidikan Islam harus sejalan dan memperhatikan fitrah manusia terkait nilai, bakat, minat dan lain-lain sehingga dapat membentuk karakter. (3) Tujuan pendidikan Islam sesuai dengan tuntutan masyarakat dengan tidak menghilangkan nilai-nilai lokal yang bersumber dari budaya dan nilai-nilai ilahiyah demi menjaga keselamatan dan peradaban umat manusia. (4) Tujuan pendidikan Islam harus sejalan dengan keinginan manusia untuk mencapai kebahagiaan hidup yang tidak semata-mata mementingkan urusan dunia tetapi adanya keseimbangan antara kehidupan dunia dan kehidupan akhirat.

Tujuan pendikan Islam menurut Abuddin Nata dalam (Haryanti, 2014) memiliki ciri-ciri yaitu: (1) Menggerakkan manusia agar dapat menjadi khalifah di muka bumi dengan sebaik-baiknya yaitu dengan melaksanakan tugas-tugas, memakmurkan dan mengolah bumi sesuai dengan kehendak Allah. (2) Menggerakkan manusia agar seluruh pelaksanaan tugas kekhalifahannya di muka bumi dilaksanakan dalam rangka beribadah kepada Allah sehingga tugas tersebut terasa ringan untuk dilaksanakan. (3) Mengarahkan manusia agarberakhlak mulia sehingga tidak menyalahgunakan fungsi kekhalifahannya. (4) Membina dan mengarahkan potensi akal, jiwa dan jasmani manusia sehingga dapat memiliki ilmu, akhlak, dan keterampilan guna mendukung tugas pengabdian dan kekhalifahannya. (5) Mengarahkan manusia agar dapat mencapai kebahagiaan dunia dan akhirat.

Menurut Abd al-Rahman Shalih Abdullah dalam (Sanusi \& Suryadi, 2018) tujuan pendidikan Islam antara lain: (1) Tujuan pendidikan jasmani, maksudnya yaitu mempersiapkan manusia sebagai pengemban tugas khalifah melalui keterampilan fisik. Peran penting manusia adalah mampu mengolah, mengatur dan mengekplorasi sumber daya alam. (2) Tujuan pendidikan ruhani, maksudnya yaitu setiap proses pendidikan bertujuan untuk meningkatkan iman dan kekuatan jiwa sehingga mampu menunjukkan dirinya untuk taat dan patuh kepada perintah Allah dan melaksanakan moralitas islami yang diteladankan oleh Nabi Muhammad saw. dengan berdasarkan pada cita-cita ideal dalam Islam. (3) Tujuan pendidikan akal, maksudnya yaitu mengarahkan kepada perkembangan intelektual manusia untuk menemukan kebenaran dan sebab-sebabnya dengan mencermati dan menelaah tanda-tanda kekuasan-Nya dan menemukan pesan ayat-Nya sehingga dapat meningkatkan keimanan. (4) Tujuan pendidikan sosial, maksudnya yaitu pendidikan Islam bertujuan sebagai pembentukan kepribadian yang utuh yang menjadi bagian dari komunitas sosial. Manusia tercermin sebagai al-nas yaitu manusia sebagai makhluk sosial yang hidup secara berkelompok dan bermasyarakat.

Berdasarkan beberapa uraian di atas, dapat dipahami bahwa pendidikan Islam merupakan upaya mengembangkan seluruh potensi individu dan sosial manusia

Paris Langkis

Vol.2 Nomor 1, Agustus 2021 
menuju terbentuknya kepribadian muslim yang berdasarkan ajaran agama Islam yaitu al-Qur'an dan hadis. Pendidikan Islam merupakan pendidikan yang berupaya mengembangkan seluruh potensi dan kemampuan individu secara optimal baik menyangkut jasmani, ruhani, akal, dan akhlak sehingga dapat mengantarkan individu tersebut ke arah kedewasaan pribadi secara paripurna yaitu yang beriman, berilmu pengetahuan, dan memiliki sikap yang baik dalam kehidupan (Saefulloh, Syarif, \& Dahlan, 2019). Tujuan pendidikan Islam adalah menjadikan manusia sebagai makhluk yang baik dan menumbuhkan pola kepribadian manusia melalui latihan kejiwaan, kecerdasan otak, penalaran, perasaan dan indra. Tujuan terakhir dari pendidikan Islam itu sendiri adalah realisasi sikap penyerahan diri sepenuhnya kepada Allah baik secara perorangan maupun sebagai umat manusia secara keseluruhannya.

\section{Pendidikan Moral dan Relevansinya dengan Pendidikan Islam}

Pada dasarnya moral merupakan bagian yang tidak dapat dipisahkan dari eksistensi keberadaan manusia (Pratama \& Karakter, 2021). Adanya panutan nilai, moral dan norma dalam diri manusia dan kehidupan akan menentukan totalitas dan jati diri manusia tersebut. Oleh karena itu, pendidikan moral merupakan salah satu pendidikan yang esensial bagi pengembangan manusia seutuhnya dalam konteks sosial (Sinulingga, 2016). Sedangkan menurut (Ibda, 2012) pada dasarnya upaya pencerdasan moral telah dilakukan pada sekolah-sekolah di Indonesia yaitu dengan diberikannya pelajaran Pendidikan Pancasila dan Kewarganegaraan (PPKn) serta Pendidikan Agama Islam sebagai mata pelajaran. Pendidikan moral melalui pengajaran PPKn adalah salah satu upaya yang ditempuh untuk membentuk dan mengembangkan budi pekerti seseorang, melestarikan nilai luhur dan moral yang berakar pada budaya bangsa sehingga diwujudkan dalam bentuk perilaku sehari-hari baik sebagai makhluk ciptaaan Allah, sebagai individu maupun sebagai anggota masyarakat. Demikian pula pengajaran pendidikan agama Islam yang bertujuan untuk meningkatkan keimanan, penghayatan, pemahaman, dan pengamalan terhadap agama Islam sehingga menjadi manusia yang beriman dan bertakwa kepada Allah SWT dan diaktualisasikan dengan berakhlak mulia dalam kehidupan seharihari. Dengan demikian, pengajaran pendidikan agama Islam merupakan salah satu upaya yang ditempuh dalam membentuk perilaku moral individu.

Menurut Muhmidayeli dalam (Frimayanti, 2015) pendidikan sebagai suatu kegiatan mulia dalam Islam selalu mengandung nilai-nilai kebaikan dan kebajikan bagi umat manusia karena aktivitas pendidikan bertujuan menjadikan manusia sebagai makhluk yang bernilai moral. Dalam konteks pendidikan Islam, nilai-nilai moral keagamaan menjadi hal yang urgen dalam setiap gerak usaha kependidikan yang tidak hanya tercantum dalam tujuan institutional pendidikan saja tetapi juga terjalin erat dalam setiap denyut nadi aktifitasnya. Menurut Quthb dalam (Hamriah, 2012) menyatakan bahwa hakekat pendidikan Islam adalah pembinaan rohani, pembinaan jasmani dan pembinaan intelektual. Dengan kata lain, pendidikan Islam merupakan usaha untuk mendidik jiwa, membina mental intelektual dan melatih fisik manusia agar bersikap sopan, jujur sebagai wujud akhakul karimah. Olehnya itu, apabila nilai-nilai moral dan akhlak tidak diajarkan atau diterapkan dalam kehidupan

Paris Langkis

Vol.2 Nomor 1, Agustus 2021 
sehari-hari maka manusia hanya akan mementingkan duniawi semata dan akan mengakibatkan kekosongan iman dan kekosongan dari norma-norma agama. Untuk itu, pendidikan moral memiliki relevansi dengan pendidikan Islam sebagaimana QS. al-Hujurat/49:13

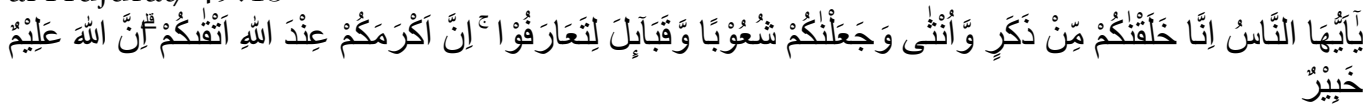

Terjemahnya:

Wahai manusia, sesungguhnya Kami telah menciptakan kamu dari seorang lakilaki dan perempuan. Kemudian, Kami menjadikan kamu berbangsa-bangsa dan bersuku-suku agar kamu saling mengenal. Sesungguhnya yang paling mulia di antara kamu di sisi Allah adalah orang yang paling bertakwa. Sesungguhnya Allah Maha Mengetahui lagi Mahateliti.

Pendidikan moral dapat dipahami sebagai pendidikan yang juga berpedoman pada sumber pendidikan Islam yaitu al-Qur'an dan hadis. Sebagaimana firman Allah dalam QS. al-Imran3:159

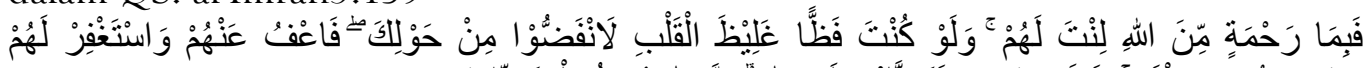

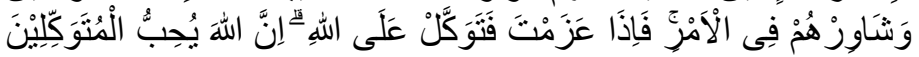

Terjemahnya:

Maka, berkat rahmat Allah engkau (Nabi Muhammad) berlaku lemah lembut terhadap mereka. Seandainya engkau bersikap keras dan berhati kasar, tentulah mereka akan menjauh dari sekitarmu. Oleh karena itu, maafkanlah mereka, mohonkanlah ampunan untuk mereka, dan bermusyawarahlah dengan mereka dalam segala urusan (penting). Kemudian, apabila engkau telah membulatkan tekad, bertawakallah kepada Allah. Sesungguhnya Allah mencintai orang-orang yang bertawakal.

Selanjutnya, di dalam hadis yang diriwayatkan Imam Ath Tabrani dari Abdullah bin Umar r.a bahwa Rasulullah SAW bersabda: "Orang mukmin yang paling baik keislamannya ialah orang yang dapat menjaga lidah dan tangannya sehingga tidak menyakiti orang muslim lainnya. Dan orang mukmin yang paling baik keimanannya ialah yang paling baik akhlaknya. Dan orang yang berhijrah yang paling baik ialah orang yang berhijrah dari (meninggalkan) apa yang dilarang oleh Allah. Adapun sebaik-baiknya jihad ialah jihad dalam memerangi hawa nafsu hanya karena Allah.

Berdasarkan beberapa uraian, ayat dan hadis di atas, dapat dipahami bahwa pendidikan moral memiliki relevansi dengan pendidikan Islam karena pendidikan moral merupakan pendidikan interdisipliner yang terdapat unsur-unsur pendidikan Islam didalamnya. Begitu pula sebaliknya, pendidikan Islam juga memiliki unsurunsur dan nilai-nilai yang terkandung dalam pendidikan moral (Dalam agama ada etika, dan sebaliknya agama merupakan salah satu norma dalam etika). Selain itu, perlu dipahami bahwa pada dasarnya pendidikan moral (akhlak) telah diajarkan oleh syariat/pendidikan Islam untuk kebaikan dan memberi manfaat bagi seluruh umat manusia. 


\section{KESIMPULAN}

Moral merupakan pandangan tentang baik dan buruk, benar dan salah, sesuatu hal yang dapat dilakukan dan tidak dapat dilakukan dalam kehidupan. Pendidikan moral sangat penting dan diperlukan agar setiap individu menyadari pentingnya nilai-nilai moral karena nilai moral tersebut dapat dijadikan sebagai pedoman dalam bertingkah laku dan bersikap baik sebagai individu maupun dalam masyarakat. Pendidikan Islam merupakan pendidikan yang berupaya mengembangkan seluruh potensi dan kemampuan individu secara optimal baik menyangkut jasmani, ruhani, akal, dan akhlak sehingga dapat mengantarkan individu ke arah kedewasaan pribadi secara paripurna yaitu yang beriman, berilmu pengetahuan, dan memiliki sikap yang baik dalam kehidupan. Pendidikan Islam merupakan ajaran tentang nilai-nilai dan norma-norma kehidupan yang ideal bersumber dari al-Qur'an dan hadis sehingga dalam hal ini pendidikan harus dipahami, dianalisis serta dikembangkan dari sumbernya yaitu al-Qur'an dan hadis tersebut. Tujuan pendidikan Islam adalah menjadikan manusia sebagai makhluk yang baik dan menumbuhkan pola kepribadian manusia melalui latihan kejiwaan, kecerdasan otak, penalaran, perasaan dan indra. Hakekat pendidikan Islam adalah pembinaan rohani, pembinaan jasmani dan pembinaan intelektual. Untuk itu, pendidikan moral hendaknya berlandaskan pada sumber pendidikan Islam itu sendiri yaitu al-Qur'an dan hadis karena pada kenyataannya pendidikan moral dan pendidikan Islam memiliki relevansi dan saling terkait satu sama lain.

\section{DAFTAR PUSTAKA}

Ananda, R. (2017). Implementasi Nilai-nilai Moral dan Agama pada Anak Usia Dini. Jurnal Obsesi : Jurnal Pendidikan Anak Usia Dini, 1(1), 19-31. https://doi.org/10.31004/obsesi.v1i1.28

Fitri, Z. (2016). PEMIKIRAN PROF. DR. ZAKIAH DARADJAT, MA. TENTANG PENDIDIKAN MORAL (Analisis Buku Membina Nilai-nilai Moral Di Indonesia).

Frimayanti, A. I. (2015). Implementasi Pendidikan Nilai dalam Pendidikan Agama Islam. 6(November), 199-216.

Hamriah. (2012). Pendidikan Islam Dan Pembinaan Etika Moral [. 7(2), 13-19.

Haryanti, N. (2014). Ilmu Pendidikan Islam. Malang: Penerbit Gunung Samudera.

Ibda, F. (2012). Pendidikan Moral Anak Melalui. Jurnal Ilmiah DIDAKTIKA, XII(2), 338347.

Kamus Besar Bahasa Indonesia. (2017). Kementerian Pendidikan dan Kebudayaan (Ed. Kelima). Jakarta.

Khaironi, M. (2017). Pendidikan Moral Pada Anak Usia Dini. Jurnal Golden Age, 1(01, Juni). https://doi.org/10.29408/goldenage.v1i01.479

Kurnia, Y. (2015). Pengembangan Kemampuan Nilai-nilai Agama dan Moral di TK. Bandung: PPPPTK TK dan PLB.

Machmud, H. (2014). Urgensi Pendidikan Moral dalam Membentuk Kepribadian Anak. Jurnal Al - Ta'dib, 7(No.2, Juli-Desember).

Pratama, D., \& Karakter, M. N. (2021). PROFESIONALITAS GURU MELALUI PENDEKATAN EMPAT PILAR PENDIDIKAN DALAM MENGEMBANGKAN 


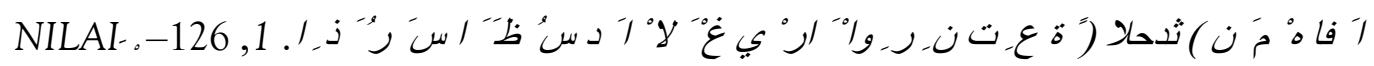
139.

Rohman, M., \& Hairudin. (2018). Konsep Tujuan Pendidikan Islam Perspektif Nilai-nilai Sosial-kultural. Al-Tadzkiyyah: Jurnal Pendidikan Islam, 9(1), 21-35.

https://doi.org/10.24042/atjpi.v9i1.2603

Rubini. (2019). Pendidikan Moral Dalam Persfektif Islam. Jurnal Komunikasi Dan Pendidikan Islam, 8(1), 225-271.

Saefulloh, A., Syarif, M., \& Dahlan, D. (2019). Model Pendidikan Islam bagi Pecandu Narkotika. In CV. Budi Utama (Deepublish).

Sanusi, U., \& Suryadi, R. A. (2018). Ilmu Pendidikan Islam. Yogyakarta: Deepublish.

Sauri, S. (2010). Meretas Pendidikan Nilai. Bandung: Arfino Raya.

Sinulingga, S. P. (2016). Teori Pendidikan Moral Menurut Emile Durkheim Relevansinya Bagi Pendidikan Moral Anak Di Indonesia. Jurnal Filsafat, 26(2), 214-248. https://doi.org/10.22146/jf.12784

Sugiyono. (2017). Metode Penelitian Kuantitatif, Kualitatif, dan REDD. Bandung: Alfabeta.

Surur, M. (2010). Problematika Pendidikan Moral di Sekolah dan Upaya Pemecahannya. Jurnal Fikroh, 4(2), 126-136.

Sutrisno. (2020). Internalisasi pendidikan moral pada perguruan tinggi di Jepang. Jurnal Civics: Media Kajian Kewarganegaraan, 17(1), 50-59. https://doi.org/10.21831/jc.v17i1.30338

Syafe'i, I. (2015). Tujuan Pendidikan Islam. Jurnal Pendidikan Indonesia, 6(6), 151-166. Syaparuddin, S. (2020). Peranan Pendidikan Nonformal Dan Sarana Pendidikan Moral. Jurnal Edukasi Nonformal, 1(1), 173-186.

Yusuf, S. (2014). Psikologi Perkembangan Anak $\mathcal{E}$ Remaja. Bandung: Anggota IKAPI.

Zuriah, N. (2011). Pendidikan Moral $\mathcal{E}$ Budi Pekerti Dalam Perspektif Perubahan. Jakarta: PT Bumi Aksra. 